\title{
A PRELIMINARY ASSESSMENT OF FOREST CANOPY Structure In Grand Teton NATIONAL PARK
}

\author{
CLAYTON F. BLODGETT $\uparrow$ DEPARTENT OF GEOGRAPHY \\ KANSAS BIOLOGICAL SURVEY $\uparrow$ UNIVERSITY OF KANSAS \\ LAWRENCE \\ MARK E. JAKUBAUSKAS $\uparrow$ DEPARTMENT OF GEOGRAPHY \\ UNIVERSITY OF OKLAHOMA $\downarrow$ NORMAN
}

\begin{abstract}
$\downarrow \quad$ INTRODUCTION
The potential impact of environmental change on human welfare has renewed interest in understanding the patterns and processes associated with global climate change. Goals of the Committee on Earth Sciences (1989) regarding the U.S. Global Climate Change Program concentrated on the development of sound scientific strategies for monitoring and predicting environmental change. The scaling of ecological characteristics from local to regional and global scales were identified by the Committce as key priorities.
\end{abstract}

The scaling of ecological information is not simply done by integrating or aggregating information from local scale investigations to regional and global scales (Caldwell et al., 1993). The complexity of the effects of scale variations rules out the use of simple generalizations (Foody and Curran, 1994). Information that is significant at local scales may be trivial when evaluated at regional or global scales. Biological interactions with the environment occur over many scales, suggesting a role for multiscale analysis in the description of these interactions (Schneider, 1994).

Methods must be developed to better understand and evaluate ecological processes operating at multiple scales.

Forest structure attributes have been measured using remotely sensed data. Leaf area index (LAI), for example, has been related to the infrared/red ratio (Running et al., 1986; Peterson et al., 1987), the normalizcd difference vegetation index (NDVI) (Leblon et al., 1993), and gap fractions ( $\mathrm{Nel}$ and Wessman, 1993). These methods generate values for each pixel in a satellite scene based on the relationship between one or more spectral and/or ancillary data channels and the attribute of interest. The spatial autocorrclation or spatial dependence present in surface phenomena and satellite data are usually not exploited during attribute assignment bocause of difficulty in quantifying the spatial patterns present (Woodcock et al., 1988). Geostatistics provides a statistically based technique to quantify spatial pattern.

Geostatistical techniques, in particular cokriging, can serve as an efficient means of modeling forest canopy structure at a variety of spatial scales to serve as inputs to global change models. The key issue will be to determine the factors that influence remotely sensed spectral reflectance and relating them to the ecological model across scales (Ustin et al., 1993).

The geostatistical techniques considered in this rescarch include the following: the semivariogram, which allows the user to compare values of a random variable at two points separated by a given lag distance (Milne, 1991); kriging which uses the information on spatial dependence present in the semivariogram to estimate values at unsampled locations based on scattercd sample data (Isaaks and Srivastava, 1989); and 
cokriging, the multivariate extension of kriging, which is appropriate when two or more variables are spatially interdependent and the variable of interest is undersampled (McBratney and Wcbster, 1983; Leenaers et al., 1989).

Geostatistical techniques have been successfully applied to remotely sensed data. Variograms have been used to determine components of coniferous canopy structure (Cohen et al., 1990), and to determine the spatial autocorrelation structure of Landsat Thematic Mapper (TM) imagery and intercepted photosynthetically active radiation (IPAR) (Lathrop and Pierce, 1991). Atkinson et al. (1992) used cokriging of ground-based radiometer data to estimate LAI, dry biomass and percent cover. Satellite imagery is an excellent candidate for inclusion as an explanatory variable in the cokriging process because it is an exhaustive sample of a given area.

\section{$\uparrow \quad$ OBJECTIVES} objectives:

This research project has the following

1. To develop models of forest structure (LAI, canopy biomass, surface roughness (average tree height), and basal area) using cokriging of field survey data with Landsat TM, MSS and NOAA AVHRR satellite data.

2. To deternine if forest structure can be adequately represented at a variety of spatial scales using the forest structure models.

3. To determine the biotic and abiotic variables that define spectral variance and forest structure attributes across multiple spatial scales.

\section{STUDY AREA}

The research is being conducted in the Greater Yellowstone Ecosystem (GYE). This area is home to Yellowstone and Grand Teton National Parks, seven National Forests (Bridger-Teton, Shoshone, Custer, Gallatin, Beaverhcad, Targhee and Caribou), an elk refuge and two wildlife refuges. Marston and Anderson (1991) define the GYE as the Yellowstone Plateau and surrounding mountain ranges above the $2130 \mathrm{~m}$ contour. Major vegetation communities include foothill grassland/shrub steppe, riparian, mountain shrub, lowelevation forest, middle-elevation forest, subalpine forest and alpine tundra. The low-elevation forest is dominated by Douglas fir Pseudotsuga menziesii, the middle-elevation forests by lodgepole pine Pinus contorta var. latifolia and the subalpine forest by Engleman spruce Picea engelmannii, subalpine fir Abies lasiocarpa and whitebark pine Pinus albicaulis (Marston and Anderson, 1991). In the middle-elevation forest, lodgepole pine is a persistent dominant and extends from the Absaroka Range in eastern Yellowstone National Park, across the Bridger-Teton National Forest to the south flank of the Teton Range (Clark, 1981).

\section{$\downarrow$ METHOdOLOGY}

Preliminary field surveys were conducted during the summer of 1994 to gather initial data on stand structure and dynamics in the Grand Teton forests. Field surveys consisted of systematic sampling of stand parameters within a $20 \times 25 \mathrm{~m}$ plot. All trees within the plot were tallied in 5 centimeter diameter classes by species. Secdlings were tallied in four height classes: $0.5-1.0 \mathrm{~m}, 1.0-1.5 \mathrm{~m}, 1.5-2.0 \mathrm{~m}$, and $2.0-2.5 \mathrm{~m}$, by species. Increment cores were extracted from dominant trees that appeared to represent the pioneer cohort of each plot to estimate the year of stand origin. Average height of the overstory was calculated using a clinometer. Visual estimates of cover by understory vegetation were recorded by species within twenty $0.5 \mathrm{~m}$ $\mathrm{x} 0.5 \mathrm{~m}$ quadrats established at equal intervals along four transects (five quadrats/transect). Ground cover not occupied by herbaceous or low woody plants was classified by percent cover into moss/lichen, litter, persistent litter, rock, or soil.

Following field work, overstory density, seedling density, total density, number of seedlings by species, dead density, basal area, and biomass were computed from size-class data collected for each stand (4 tree species and standing dead $\times 16$ diameter classes), normalizing data to a one hectare standard unit. Basal area was for living and dead trees was computed using the mean diameter value for each size class (e.g., $2.5 \mathrm{~cm}$ for the $0.0 \mathrm{~cm}-5.0 \mathrm{~cm}$ size class). Biomass for living overstory species was computed using the allometric equations from Gholz et al. (1979). Leaf area index (LAI) was computed for each stand using the basal area equations of Kaufman et al. (1982). Total percent understory living cover, and percent cover by life form (e.g., shrubs, grasses, and forbs) was computed for each plot. 


\begin{tabular}{|c|c|c|c|c|c|c|}
\hline \multicolumn{2}{|l|}{ Table 1. Stand Structure by Plot } \\
\hline \hline Plot \# & $\begin{array}{l}\text { Age of } \\
\text { Origin }\end{array}$ & $\begin{array}{l}\text { Density } \\
\text { (Overstory) }\end{array}$ & Seedlings & Basal Area & Biomass & LAI \\
\hline 1 & 93.5 & 2,420 & 8,880 & 48.94 & $10,890.94$ & 10.56 \\
\hline 2 & 110.8 & 2,260 & 2,540 & 46.42 & $9,950.46$ & 8.08 \\
\hline 3 & 89.6 & 1,360 & 2,260 & 28.71 & $6,094.44$ & 5.05 \\
\hline 4 & 102.4 & 1,820 & 360 & 33.88 & $7,281.12$ & 5.9 \\
\hline 5 & 104.2 & 1,600 & 3,480 & 30.63 & $6,768.13$ & 5.8 \\
\hline 6 & 132 & 1,300 & 5,800 & 30.09 & $8,297.87$ & 10.6 \\
\hline 7 & 82.75 & 1,180 & 1,200 & 27.83 & $5,899.97$ & 5 \\
\hline 8 & 102 & 900 & 1,020 & 30.91 & $6,308.18$ & 5.39 \\
\hline 9 & 102.6 & 1,840 & 80 & 24.7 & $5,421.65$ & 4.3 \\
\hline 10 & 103.4 & 720 & 720 & 20.85 & $4,369.04$ & 3.97 \\
\hline 11 & 116 & 1,300 & 4,100 & 42.11 & $9,192.06$ & 8.91 \\
\hline 12 & 115.5 & 940 & 4,220 & 16.4 & $3,698.58$ & 3.64 \\
\hline 13 & 89.8 & 800 & 1,380 & 28.04 & $6,294.69$ & 6.77 \\
\hline 14 & 79 & 880 & 400 & 26.11 & $5,246.09$ & 4.55 \\
\hline 15 & 108.6 & 1,480 & 3,820 & 29.55 & $6,279.39$ & 5.31 \\
\hline
\end{tabular}

\section{$\uparrow \quad$ RESULTS}

A total of fifteen sites were sampled during the 1994 field season. A total of 88 trees were cored, of which 67 were Pinus contorta var. latifolia, 18 were Abies lasiocarpa and 3 were Picea engelmannii. The

average age of origin for the plots sampled was approximately 102 before present, with a standard deviation of approximately 13 years. Only three plots fell outside plus or minus one standard deviation from the mean age of origin, even though structurally, the stands are quite different (Table 1.) Additional analyses will be performed, including detrended correspondence analysis and cluster analysis, after incorporating additional data from the 1995 field season.

\section{CONCLUSION}

This research will develop new methodologies for generating forest canopy structure variables from satellite data. A key shortcoming of existing methods for determining forest structure from remotely sensed data (Running et al., 1986; Peterson et al., 1987; Leblon ct al., 1993; Nel and Wessman, 1993) is the lack of accuracy or error assessment associated with each measure (Asrar, 1989). Cokriging provides the error variance as part of the output from the algorithm and examination of the error variance indicates if the results of the tochnique are acceptable. Model comparison will determine if local forest structure information can be adequately represented as the spatial resolution of the 
satellite data becomes coarser. This will indicate the potential of scaling forest structure variables to regional and global levels using satellite data in conjunction with geostatistical techniques.

\section{Literature Cited}

Asrar, G. 1989. Theory and Application of Optical Remote Sensing. John Wiley \& Sons, Inc. $734 \mathrm{p}$.

Atkinson, P.M., Webster R, and Curran P.J. 1992. Cokriging with Ground-Based Radiometry. Remote Sensing of Environment, 41:45-60.

Caldwell, M.M., Matson, P.A., Wessman, C., and Gamon, J. 1993. Prospects for Scaling. In Ehleringer, J.R., and Field, C.B. (eds), Scaling Physiological Processes: Leaf to Globe. Academic Press. p.223-230.

Clark, T.W. 1981. Ecology of Jackson Hole, Wyoming. Paragon Press. $110 \mathrm{p}$.

Cohen, W.B., Spies, T.A., and Bradshaw, G.A. 1990. Semivariograms of Digital Imagery for Analysis of Conifer Canopy Structure. Remote Sensing of Environment, 34:167-178.

Committee on Earth Sciences. 1989. Our Changing Planet: The FY 1990 Research Plan. A Report by the Committee on Earth Sciences. $118 \mathrm{p}$.

Foody, G.M., and Curran, P.J. 1994. Scale and Environmental Remote Sensing. In Foody, G.M., and Curran, P.J. (eds.), Environmental Remote Sensing from Regional to Global Scales. John Wiley \& Sons. p. 223-232.

Gholz, H.L., Grier, C.C., Campbell, A.G., and Brown, A.T. 1979. Equations for Estimating Biomass and Leaf Area of Plants in the Pacific Northwest. Research Paper 41, Forest Research Laboratory, School of Forestry, Oregon State University, Corvallis, Oregon. $22 \mathrm{p}$.

Isaaks, E.H., and Srivastava, R.M. 1989. An Introduction to Applicd Gcostatistics. Oxford University Press. $561 \mathrm{p}$.
Kaufman, M.R., Edminster, C.B., and Troendle, C.A. 1982. Leaf Area Determination for Subalpine Tree Species in the Central Rocky Mountains. Rocky Mountain Forest and Range Experiment Station Research Paper RM-238. U.S. Forest Service, Department of Agriculture. $7 \mathrm{p}$.

Lathrop, R.G., and Pierce, L.L. 1991. Ground-Based Canopy Transmittance and Satellite Remotely Sensed Measurements for Estimation of Conifer Forest Canopy Structure. Remote Sensing of Environment, 36:179-188.

Leblon, B., Gransberg, H., Ansseau, C., and Royer, A. 1993. A Semi-Empirical Model to Estimate the Biomass Production of Forest Canopies from Spectral Variables Part 1: Relationship Between Spectral Variables and Light Interception Efficiency. Remote Sensing Reviews, 7:109-125.

Lecnaers, H, Burrough, P.A., and Okx, J.P. 1989. Efficient Mapping of Heavy Metal Pollution on Floodplains by Cokriging from Elevation Data. In Raper, J. (ed), Three Dimensional Applications in Geographical Information Systems. Taylor and Francis. p. 37-50.

Marston, R.A., and Anderson, J.E. 1991. Watersheds and Vegetation of the Greater Yellowstone Ecosystem. Conservation Biology, 5:338-346.

McBratney, A.B., and Webster, R 1983. Optimal Interpolation and Isarithmic Mapping of Soil Propertics: V. Coregionalization and Multiple Sampling Strategy. Journal of Soil Science, 34:137-162.

Milne, B.T. 1991. Lessons from Applying Fractal Models to Landscape Patterns. In Turner, M.G. and Gardner, R.H. (eds.), Quantitative Methods in Landscape Ecology. SpringerVerlag. p.199-235.

Nel, E.M., and Wessman, C.A. 1993. Canopy Transmittance Models for Estimating Forest Leaf Area Index. Canadian Journal of Forest Research, 23:2579-2586. 
Peterson, D.L., Spanner, M.A., Running, S.W., and Teuber, K.B. 1987. Relationship of Thematic Mapper Simulator Data to Leaf Area Index of Temperate Coniferous Forests. Remote Sensing of Environment, 22:323-341.

Running, S.W., Peterson, D.L., Spanner, M.A., and Teuber, K.B. 1986. Remote Sensing of Coniferous Forest Leaf Area Ecology, 67:273-276

Schneider, D.C. 1994. Quantitative Ecology: Spatial and Temporal Scaling. Academic Press. $395 \mathrm{p}$.
Ustin, S.L., Smith, M.O., and Adams, J.B. 1993. Remote Sensing of Ecological Processes: A Strategy for Developing and Testing Ecological Models Using Spectral Mixture Analysis. Prospects for Scaling. In Ehleringer, J.R., and Field, C.B. (eds), Scaling Physiological Processes: Leaf to Globe. Academic Press. p.339-357.

Woodcock, C.E., Strahler, A.H., and Jupp, D.L.B. 1988. The Use of Variograms in Remote Sensing: I. Scene Models and Simulated Images. Remote Sensing of Environment, 25:323-348 